\title{
Model Project Construction of Vocational College: from Perspective of Project Management
}

\author{
Haoyu Tan ${ }^{1, a}$, Jianquan $\mathrm{Li}^{2}$, b, Sun Wenxing ${ }^{1, c}$ \\ ${ }^{1}$ Office of Educational Administration, Kunming Metallurgy College, Kunming, 650033, China \\ ${ }^{2}$ Logistics Engineering and Management Faculty, Kunming Metallurgy College, Kunming, 650033, \\ China \\ aemail: 735872451@qq.com, bemail:2361371418@qq.com, cemail: 353639220@qq.com
}

Keywords: Vocational College; Construction of Model Project; Existing Problems; Countermeasures and Suggestions

\begin{abstract}
Basic contents about the background of the construction plan and project management of national model vocational college are introduced first in this paper. Subsequently, construction of model project of College A is briefly summarized from perspectives of basic tool method of project management. On the basis of this, the problems existing in the model project construction of College A are stressed and analyzed, and, finally, corresponding countermeasures and policy suggestions are put forward.
\end{abstract}

\section{Background}

In November 2010, Ministry of Education and Ministry of Finance implemented "Construction Plan of National Model Vocational College". It is a significant initiative to carry out strategic deployment of the Party Central Committee and State Council to lay the stress of higher education development on the improvement of quality and spirits of Decision of State Council to Vigorously Develop Vocational Education and implement scientific development outlook in education. The plan is mainly aimed to support and construct 100 vocational colleges in principle of "local domination, central leadership, emphasis of key point and coordinated development" to make them into the models of development, reform and management. The plan is significant during the critical period when the emphasis of higher vocational education developed is fully shifted from size expansion to connotation construction. After application and approval, College A is included into vocational colleges of the plan and sees the new stage of development.

Project management is a modern management mode. As an advanced management method, it is introduced into the process of project construction management of "Construction Plan of National Model Vocational College". The biggest advantage and feature of the mode are effectiveness and practicability, which can be fully reflected from the scope, time, expense, quality, human resource, communication, risk and overall management of the project. Project management runs through the entire life cycle of a project. It is an organized and economical method as well as a measure to effective plan, organize, instruct and control. It can achieve planned objectives of time, expense and technical effect. Project of "Construction Plan of National Model Vocational college" has specific time, expense, quality limits, constrains and a series of construction objectives such as construction of key major and major cluster project, construction of training base, public service system, infrastructures and scientific and technological innovation platform.

\section{Overview of model project construction of College A}

\section{Scope of construction plan of model construction scheme}

Scope planning is a process to progressively specify and file the project work (project scope) essential for the production of project product. The state requires model-building schools to use an open method to establish majors. In fact they are required to become a cradle that can combine the industry and society tightly and offer skilled talents with professional ethics and scientific 
innovation spirits. This requirement indicates that the final goals of model-building schools are the same but the specific construction project scopes of different model schools are different.

According to "Preliminary Review Standard for Construction Project of National Model Vocational college (Provisional)" indexes required to be completed in the higher vocational model application plan are shown in Table 1.

Table 1. Preliminary Review Standard List of Construction Project of National Model Vocational College

\begin{tabular}{|c|c|c|c|c|c|c|}
\hline $\begin{array}{c}\text { Serial } \\
\text { No. }\end{array}$ & 1 & 2 & 3 & 4 & 5 & 6 \\
\hline $\begin{array}{l}\text { First-class } \\
\text { indexes }\end{array}$ & $\begin{array}{l}\text { Construction } \\
\text { environment }\end{array}$ & Leadership & $\begin{array}{l}\text { General } \\
\text { ability }\end{array}$ & $\begin{array}{l}\text { Educational } \\
\text { reform }\end{array}$ & $\begin{array}{c}\text { Major } \\
\text { construction }\end{array}$ & Social service \\
\hline \multirow{5}{*}{$\begin{array}{l}\text { Second-level } \\
\text { indexes }\end{array}$} & $\begin{array}{l}\text { Support of } \\
\text { provincial } \\
\text { government }\end{array}$ & $\begin{array}{c}\text { Leaders of } \\
\text { school }\end{array}$ & $\begin{array}{l}\text { Schooling } \\
\text { philosophy }\end{array}$ & $\begin{array}{l}\text { Reform of } \\
\text { schooling } \\
\text { mode }\end{array}$ & $\begin{array}{c}\text { General } \\
\text { ability of } \\
\text { major } \\
\text { construction }\end{array}$ & $\begin{array}{l}\text { Educational } \\
\text { training } \\
\text { service }\end{array}$ \\
\hline & $\begin{array}{l}\text { Support of } \\
\text { organizer }\end{array}$ & & $\begin{array}{l}\text { Teaching } \\
\text { staff }\end{array}$ & $\begin{array}{c}\text { Reform of } \\
\text { teaching } \\
\text { mode }\end{array}$ & $\begin{array}{l}\text { Curriculum } \\
\text { construction }\end{array}$ & $\begin{array}{c}\text { Scientific and } \\
\text { technological } \\
\text { service } \\
\end{array}$ \\
\hline & $\begin{array}{l}\text { Project fund } \\
\text { guarantee }\end{array}$ & & Facility fund & & $\begin{array}{c}\text { Occupational } \\
\text { ability and } \\
\text { occupational } \\
\text { quality } \\
\text { education } \\
\end{array}$ & $\begin{array}{l}\text { Radiating and } \\
\text { driving effect }\end{array}$ \\
\hline & & & $\begin{array}{c}\text { Employment } \\
\text { quality and } \\
\text { social evaluation }\end{array}$ & & & \\
\hline & & & $\begin{array}{c}\text { Education } \\
\text { and teaching } \\
\text { management } \\
\text { and quality } \\
\text { monitoring }\end{array}$ & & & \\
\hline
\end{tabular}

For model schools, they must first clarify the definition of final product "model school construction scheme" they design and then plan the work. Scope planning requires referring to much information, such as how to reflect the higher schooling philosophy and leadership of principal; how to show self-schooling features and good schooling mode; how to present good development foundation and the features formed in regional cooperation and social service; how to carefully prepare "model school construction scheme and lay the construction stress on talent cultivation and major construction in material preparation.

\section{Model construction project scheme of College A}

The purpose to make a plan is surely to establish a detailed construction guidance scheme, tell project team what and when they must do and what resources are required and further guarantee the successful production of deliverable outcome of project. Project can be subject to many forms and major plan must include a complete set of schedule plan and relevant resource and manpower demands to implement all the tasks essential for the completion of the project.

The construction scheme of model project scheme of College A (approved) is divided into five parts (see Table 2): part 1-model construction background and foundation; Part 2-model construction idea and objective; Party 3-model construction items and contents; Part 4-model construction schedule and effect; Part 5-model construction support and budget. See Table 2. The core project construction is Part 3 "model construction items and contents" and specific construction scope of the overall objective of College A.

The early stage of a project is crucial, and project demonstration and planning are the key links, which is the general law of project management. Objective of feasible construction scheme made on the basis of geographic advantages and human resource advantages is fully presented in the model construction plan of College A. In the construction scheme of College A, eight key majors and major clusters have detailed construction plans respectively. The plans include expected achievement or binding objective, time schedule, staff organization, acceptance points, expenditure 
and budget, which lays the foundation for the breakdown and specific implementation of the construction task in the next stage of the project.

Table 2. Outline of Model Construction Item Scheme of College A

\begin{tabular}{|c|c|}
\hline Construction sub-item & Item and content \\
\hline $\begin{array}{l}\text { (I) Background } \\
\text { foundation and } \\
\text { construction }\end{array}$ & $\begin{array}{l}\text { 1. Industrial background and school features } \\
\text { 2. Analysis of talent of metallurgy and mining industry } \\
\text { 3. Existing problems }\end{array}$ \\
\hline $\begin{array}{l}\text { (II) Idea and objective of } \\
\text { model construction }\end{array}$ & $\begin{array}{l}\text { 1. Guiding ideology } \\
\text { 2. Construction idea } \\
\text { 3. General objective } \\
\text { 4. Specific objective }\end{array}$ \\
\hline $\begin{array}{l}\text { (III) Projects and contents of } \\
\text { model construction }\end{array}$ & $\begin{array}{l}\text { (I) Key construction items with central financial support } \\
\text { Item I: construction scheme of metallurgic technology major and } \\
\text { major cluster } \\
\text { Item II: construction scheme of surveying and mapping } \\
\text { engineering technology major and major cluster } \\
\text { Item III: construction scheme of environment monitoring and } \\
\text { treatment technology major and major cluster } \\
\text { Item IV: construction scheme of inorganic nonmetallic material } \\
\text { engineering technology major and major cluster } \\
\text { (II) Key construction items without central financial support } \\
\text { Item I: (metallurgy) construction scheme of electric automation } \\
\text { technology major and major cluster } \\
\text { Item II: (metallurgy) construction scheme of architectural } \\
\text { engineering technology major and major cluster } \\
\text { Item III: metallurgy and mining technology application and digital } \\
\text { campus construction scheme of College A } \\
\text { Item IV: construction and implementation scheme of teaching } \\
\text { quality guarantee system of College A }\end{array}$ \\
\hline $\begin{array}{l}\text { (VI) Schedule and effect of } \\
\text { model construction }\end{array}$ & $\begin{array}{l}\text { 1. Staged schedule arrangement of model construction } \\
\text { 2. Expected effect analysis of model construction }\end{array}$ \\
\hline $\begin{array}{l}\text { (V) Support and budget of } \\
\text { model construction }\end{array}$ & $\begin{array}{l}\text { 1. Organization support of model construction } \\
\text { 2. Policy support of model construction } \\
\text { 3. System support of model construction } \\
\text { 4. Expenditure and budget of model construction }\end{array}$ \\
\hline
\end{tabular}

\section{Construction task breakdown and schedule arrangement of model project of College $A$}

The first-level and second-level indexes of primary review for construction of national model vocational college project show the project elements of deliverable achievement of project. These elements define and organize the general work scope of the project. Deliverable achievement of project must be gradually subdivided into WBS after the project scope is defined. The work not included in WBS is excluded from the scope of project. The lower level of WBS means the more detailed definition and description of project work. Figure 1 is the breakdown of construction tasks of College A model project.

To arrange the schedule of each major task in the work structure is a good practice method. Schedule arrangement is based on pre-determined action plan or work breakdown structure (WBS) but not all the project activities must be subject to the same arranged detailed schedule.

Break down the next level of the subproject 5.0 "employment quality and social evaluation of the construction of key (characteristic) major" of College A model construction project and arrange work time schedule: see Table 3. Time schedule of 5.3.5 social service ability construction is arranged as shown in Table 4. 


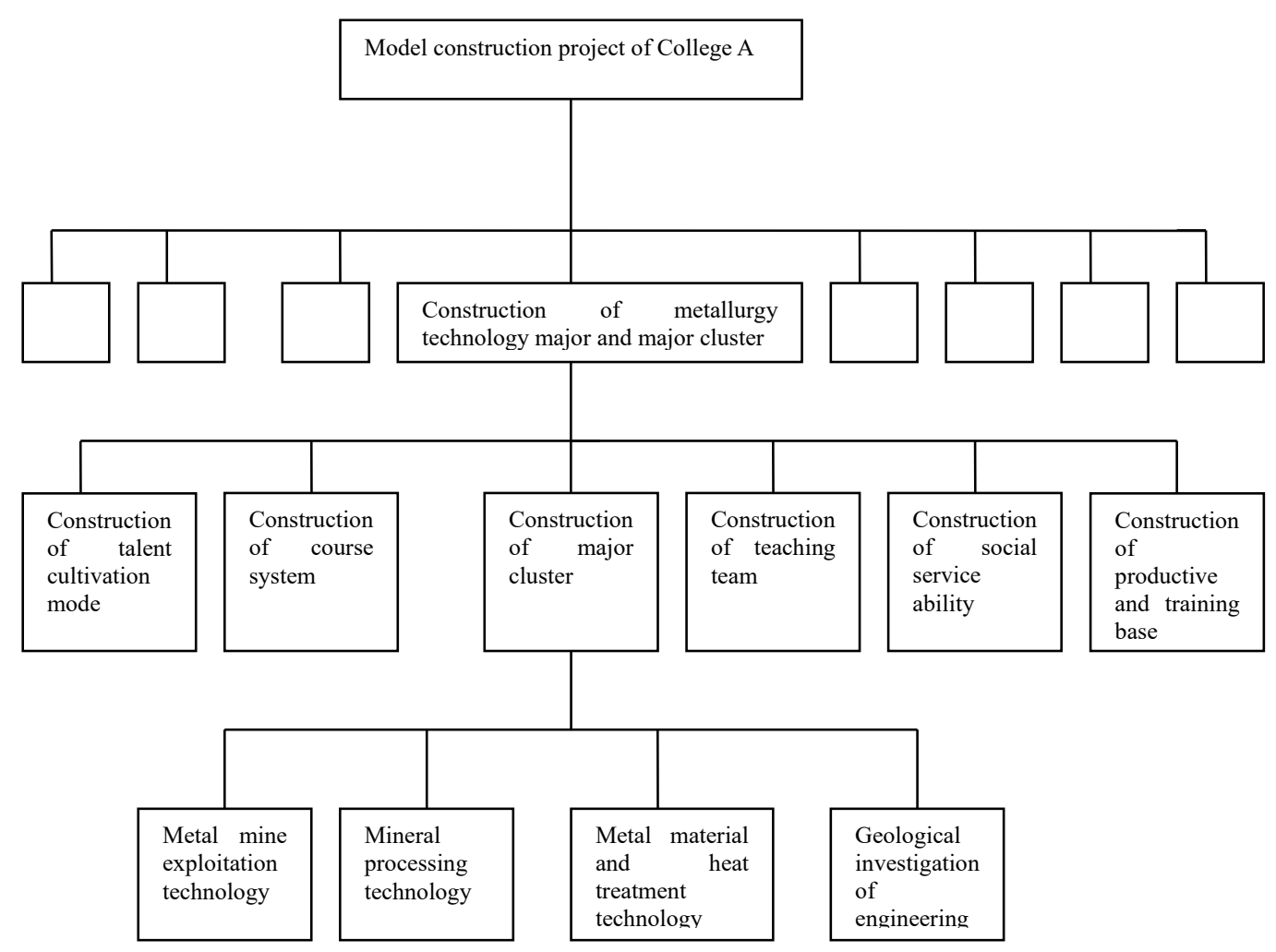

Figure 1. Breakdown of Model Construction Tasks of College A

Table 3. Gantt Chart of "Employment Quality and Social Evaluation of Key (Characteristic) Major Construction"

\begin{tabular}{|c|c|c|c|c|c|c|c|c|c|c|c|c|}
\hline \multirow{3}{*}{ Task } & \multicolumn{12}{|c|}{ End of month } \\
\hline & \multicolumn{4}{|c|}{2008} & \multicolumn{4}{|c|}{2009} & \multicolumn{4}{|c|}{2010} \\
\hline & 3 & 6 & 9 & 12 & 3 & 6 & 9 & 12 & 3 & 6 & 9 & 12 \\
\hline $\begin{array}{l}5.1 \text { Background and foundation } \\
\text { of major construction }\end{array}$ & & & & & & & & & & & & \\
\hline $\begin{array}{l}5.2 \text { Major positioning and } \\
\text { construction objective }\end{array}$ & & & & & & & & & & & & \\
\hline 5.3 Construction contents & & & & & & & & & & & & \\
\hline $\begin{array}{l}\text { 5.3.1 Construction of talent } \\
\text { cultivation mode }\end{array}$ & & & & & & & & & & & & \\
\hline $\begin{array}{l}5.3 .2 \text { Curriculum system and } \\
\text { teaching reform }\end{array}$ & & & & & & & & & & & & \\
\hline $\begin{array}{cc}5.3 .3 & \text { Construction } \\
\text { productive training base }\end{array}$ & & & & & & & & & & & & \\
\hline $\begin{array}{l}5.3 .4 \quad \text { Construction } \\
\text { teaching team }\end{array}$ & & & & & & & & & & & & \\
\hline $\begin{array}{l}\text { 5.3.5 Construction of social } \\
\text { service ability }\end{array}$ & & & & & & & & & & & & \\
\hline $\begin{array}{l}\text { 5.3.6 Supporting } \\
\text { construction of major cluster }\end{array}$ & & & & & & & & & & & & \\
\hline 5.4 Expenditure and budget & & & & & & & & & & & & \\
\hline 5.5 Expected effect & & & & & & & & & & & & \\
\hline 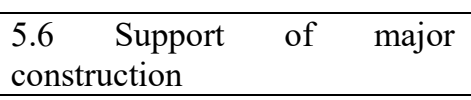 & & & & & & & & & & & & \\
\hline
\end{tabular}


Table 4. Schedule Chart of Social Service Ability Construction of Metallurgy Technology Major and Major Cluster Project of College A

\begin{tabular}{|c|c|c|c|}
\hline $\begin{array}{c}\text { Construction } \\
\text { content }\end{array}$ & 2008-2009 & 2010 & $\begin{array}{c}\text { Person } \\
\text { in } \\
\text { charge }\end{array}$ \\
\hline \multirow[b]{2}{*}{$\begin{array}{l}\text { Construction } \\
\text { of social } \\
\text { service } \\
\text { ability }\end{array}$} & $\begin{array}{l}\text { Expected objectives: } \\
\text { 1) Carry out } 4 \text { scientific research technical } \\
\text { services; } \\
\text { 2) Carry out } 40 \text { person times teacher and staff } \\
\text { trainings; } \\
\text { 3) Assess } 2,000 \text { person times employees for } \\
\text { corporate training; } \\
\text { 4) Enroll } 30 \text { foreign students dispatched by } \\
\text { Vietnam Coal Mining Group. }\end{array}$ & $\begin{array}{l}\text { Expected objectives: } \\
\text { 1) Carry out } 2 \text { scientific research technical services; } \\
\text { 2) Carry out } 20 \text { person times teacher and staff } \\
\text { trainings; } \\
\text { 3) Assess } 1.200 \text { person times employees for corporate } \\
\text { training; } \\
\text { 4) Enroll } 20 \text { foreign students dispatched by Vietnam } \\
\text { Coal Mining Group. }\end{array}$ & \multirow[b]{2}{*}{$\begin{array}{l}\text { Wang } \\
\text { Yujun }\end{array}$} \\
\hline & $\begin{array}{l}\text { Acceptance points: } \\
\text { 1) Scientific research and technical service } \\
\text { contract, technical data, project report, essay } \\
\text { and review data; } \\
\text { 2) Staff and teacher training plan, teaching } \\
\text { documents, name list and other original } \\
\text { materials; } \\
\text { 3) Joint development agreement, joint } \\
\text { development student list, teaching arrangement } \\
\text { and other original materials; } \\
\text { 4) Employee training evaluation file; } \\
\text { 5) Name list of foreign students, all kinds of } \\
\text { teaching documents and other original } \\
\text { materials. }\end{array}$ & $\begin{array}{l}\text { Acceptance points: } \\
\text { 1) Scientific research and technical service contract, } \\
\text { technical data, project report, essay and review data; } \\
\text { 2) Staff and teacher training plan, teaching documents, } \\
\text { name list and other original materials; } \\
\text { 3) Joint development agreement, joint development } \\
\text { student list, teaching arrangement and other original } \\
\text { materials; } \\
\text { 4) Employee training evaluation file; } \\
\text { 5) Name list of foreign students, all kinds of teaching } \\
\text { documents and other original materials. }\end{array}$ & \\
\hline
\end{tabular}

\section{Organization structure of model project construction of College A}

Construction of model project of College A is subject to functional organization structure and all of the detailed project constructions are completed in the original line departments. Model project construction includes a large number of quantities. When temporary item conflicts with conventional operation and the functional department has two work objectives in a time, which one should it consider first? Although they can allocate relevant staff, staff selection and recruitment of functional department will certainly arouse the dissatisfaction and complaint of other functional departments. Becoming the target of school criticism for a temporary item will make the person in charge of functional department choose to make sure his/her own duties can be completed smoothly and give up other work. From a long-term perspective, model project construction is quite beneficial for the architecture schools. So, whether to establish an organization structure system more suitable for the construction of the project is worthy thinking.

\section{Management system of model project construction of College A}

Legal person responsibility system of higher vocational model construction project is one of the major characteristics of model project management and the important mark to distinguish project management from other management. As model project management is binding management and has specific objective, time and expense constraints, it objectively requires to focus on the objective of model construction project, establish responsibility oriented on legal person of project on the basis of constraint conditions and establish objective responsibility system by use of objective decomposition and authorization inside the project organization so that every functional department or every person in the project team is responsible for their own objective, which truly realizes the unity of objective, responsibility, power, obligation, performance and interest. Only by doing this can the objective of model construction project be realized in the best way under some constraint conditions. 


\section{Problems existing in the model project construction of College A}

\section{Single project organization structure mode}

The biggest feature of implementation of "model construction project plan" lies in the construction of college project and its subordinate sub-projects. Some projects have the nature of engineering construction project, some have the nature of management project and some have the nature of research project. The project management for different projects will be subject to their own features. In the model project construction process, College A use simple functional organization to boost the construction. The work is implemented under the leadership of model office and they are the schools and teaching and research offices where the key construction majors implement the specific construction tasks. The advantage of the functional organization is that it can take full use of the resources of organization. When some staff or other resources participate in the project, person in charge of the functional department will dispatch these staff or resources to complete these tasks. When encountering difficulty or urgent project task, they can naturally continue the original duties. Disadvantage is that functional departments are only responsible for their own project tasks but not responsible for the final result of project. Undoubtedly, teaching and research office is beneficiary in the model construction. However, subjectively speaking, teaching and research office have to fulfill a large amount of conventional work. As a result, so much model construction work and daily teaching and research contents crack down the office that undertakes the model construction work. The problem is that functional departments are only responsible for project tasks rather than the final result of the project caused by the project organization structure which affects the quality of construction project.

\section{Unclear control standard}

The construction duration of "model construction" project of College A can be effectively managed by use of the item schedules. For example, define and confirm the specific contents of "model construction" project activity; sort the contents of project activity; estimate construction duration - estimate the time of each activity and then estimate the construction duration of the entire project to supervise and control the progress of the project; establish project plan to control work sequence and activity. As the sources for the control standard establishment for sub-items of College A are the acceptance points in the construction plans of teaching and research office of construction project rather than the construction or industrial performance evaluation standards of this field and teaching and research office is not the main body of project construction, the role which teaching and research office acts is athlete and referee. It cannot guarantee the objective of project construction set and expectation which the state wants to realize in the project. As the acceptance points prepared by different teaching and research offices cannot fully evaluate the quality of project construction, the quality of project completion may not be guaranteed even when the work can be done as scheduled.

\section{Social service capacity needs to be further improved in model project construction}

In a broad sense, social service function of national model vocational college refers to the services that the college uses its own resources to directly serve the society, promote scientific technology transferring to real productivity and facilitate economic construction and social development by use of industry-academy cooperation, technology promotion, technology training and technical service. As to the interior of College A, work stress of the college is laid on the talent development. Social service work of all the teachers and students is carried out but is still in the initial stage. Although College A has special scientific research management department and special "industry-academy-research education \& cooperation instruction center", social service organization and service platform are incomplete. The state of present work shows that all the teachers and staff are not organized effectively to offer advice for politics, economy and culture developments of the local society, which makes it difficult to implement social service work of the college. 


\section{Countermeasures and suggestions for model project construction of College A}

\section{Promote the diversification of organization management modes of model construction sub-items}

From the perspective of project management, organization structure of model construction sub-item must be determined according to the need of project. So determine what organization structure to use after sub-items of construction are confirmed. Besides project-type structure, other four organization forms of project management such as functional structure, weak matrix structure, balanced matrix structure and strong matrix structure may emerge in functional organization structure. They vary in project management support degrees. Especially, as the latter three matrix structures have two mutually integrated management forms, there will be large conflict between project organization crossing departments and functional department, which is mainly reflected on resource competition, objective, expectation and staff allocation. For example, in aspect of staff arrangement, the person appointed by the functional department to participate in the project tends to undertake the task of original department and task of the project. He/she will be overused and time cannot be guaranteed. In aspect of project objective, all of the functional departments hopes that they can realize more objectives they expect, which will influence the operation of entire project. From the perspective of entire project, more attention is paid to the entirety and partial interests of a part of functional departments will be sacrificed. Such contradiction happens frequently in practice. Fundamentally, the solution must lie in the organization form of project management. Proper organization form is an efficient way to improve project management.

Establish normative performance evaluation system to quantize management of model vocational college construction project

Performance evaluation system is composed of three subsystems of performance evaluation such as institution system, performance evaluation organization system and performance evaluation index system. Scientificity, practicability and operability of performance evaluation system are the premise to realize objective and fair performance evaluation of model vocational college construction. "Construction Plan of National Model Vocational College" is a national reform project and a national quality project of vocational college education in the new era. Implementation of construction of national model vocational college will drive the reform and overall quality improvement of national vocational college education. How can the quality improvement be reflected? Can schooling strength, teaching quality, management level and schooling efficiency of construction colleges be improved only when the task objectives of the construction scheme are realized? The answer is no. Construction can guarantee that the construction colleges will receive privilege but the construction result may not be the expected objective. If a set of objective and performance evaluation systems for model construction with comprehensive content, scientific method, normative system and easy operation are established, the entire model construction project will be more normative and valuable.

\section{Make efforts to extend and improve social service ability in the process of model project} construction

College A shall first attach importance to constant improvement of scientific research and service level of teachers; secondly, it provides targeted social services with major features for the society. Set up majors according to the market, design courses according to posts, teach students according to practice and adjust and renew teaching contents by simplification, integration, restructure and addition according to requirements of technical teaching system. College A can provide technical development, consultation and job training services for the society after it meets corresponding conditions, and, furthermore, it will play the role of thought tank and brain tank in the local economic construction and social development.

\section{Acknowledgements}

Thank anonymous reviewers for giving the suggestions to improve this paper. 


\section{References}

[1] Zhou Ji. Speech in video conference "Construction Plan of National Model Vocational College"[R]. November 13, 2006.

[2] Wu Qidi. Implement "Construction Plan of National Model Vocational College" and Lead Comprehensive Improvement of Education Quality of Vocational College[J]. China Higher Education Research, 2007, (1): 1-3.

[3] Jack $\cdot R \cdot$ Meredith, Samuel $\cdot J \cdot$ Mantel. Project Management: New Perspective of Management $\left(6^{\text {th }}\right.$ Edition)[M]. Beijing: Publishing House of Electronics Industry, 2006.

[4] Stiphen P. Robbins, Mary Coulter. Management ( $8^{\text {th }}$ Edition)[M]. Beijing:Tsinghua University Press, 2005.

[5] Timothy J. Kloppenberg. Contemporary Project Management ( $3^{\text {rd }}$ Edition)[M]. Beijing:China Machine Press, 2016.

[6] Sun Li, Guo Bin. Engineering Project Management[M]. Beijing:China Machine Press,2015.

[7] Karen B. Brown, Nancy Lee Hyer. Managing Projects: A Team-Based Approach [M]. Beijing:China Machine Press,2012. 